\title{
Experimental evidence of dietary ciguatoxin accumulation in an herbivorous coral reef fish
}

Clausing Rachel J. ${ }^{1}$, Losen Barbara ${ }^{1}$, Oberhaensli Francois R. ${ }^{1}$, Darius H. Taiana ${ }^{2}$, Sibat Manoella ${ }^{3}$, Hess Philipp ${ }^{3}$, Swarzenski Peter W. ${ }^{1}$, Chinain Mireille ${ }^{2}$, Bottein Marie-Yasmine Dechraoui ${ }^{1,{ }^{*}}$

${ }^{1}$ IAEA, IAEA Environm Labs, 4 Quai Antoine 1er, Monaco 98000, Monaco.

2 Inst Louis Malarde UMR 241 EIO, Lab Microalgues Tox, BP 30, F-98713 Papeete Tahiti, French Polynesi, France.

${ }^{3}$ IFREMER, Lab Phycotoxines, Rue lle Yeu, F-44311 Nantes, France.

*Corresponding author : Marie-Yasmine Dechraoui Bottein, email address : $\underline{\text { m-y.bottein@iaea.org }}$

\begin{abstract}
:
Ciguatoxins (CTXs) are potent algal toxins that cause widespread ciguatera poisoning and are found ubiquitously in coral reef food webs. Here we developed an environmentally-relevant, experimental model of CTX trophic transfer involving dietary exposure of herbivorous fish to the CTX-producing microalgae Gambierdiscus polynesiensis. Juvenile Naso brevirostris were fed a gel-food embedded with microalgae for 16 weeks (89 cells g. 1 fish daily, 0.4 ìg CTX3C equiv kg. 1 fish). CTXs in muscle tissue were detectable after 2 weeks at levels above the threshold for human intoxication (1.2 jÀ 0.2 ìg

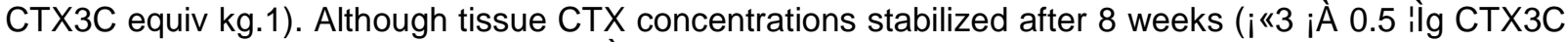
equiv kg.1), muscle toxin burden (total ilg CTX in muscle tissue) continued to increase linearly through the end of the experiment (16 weeks). Toxin accumulation was therefore continuous, yet masked by somatic growth dilution. The observed CTX concentrations, accumulation rates, and general absence of behavioural signs of intoxication are consistent with field observations and indicate that this method of dietary exposure may be used to develop predictive models of tissue-specific CTX uptake, metabolism and depuration. Results also imply that slow-growing fish may accumulate higher CTX flesh concentrations than fast-growing fish, which has important implications for global seafood safety.
\end{abstract}




\section{Graphical abstract}

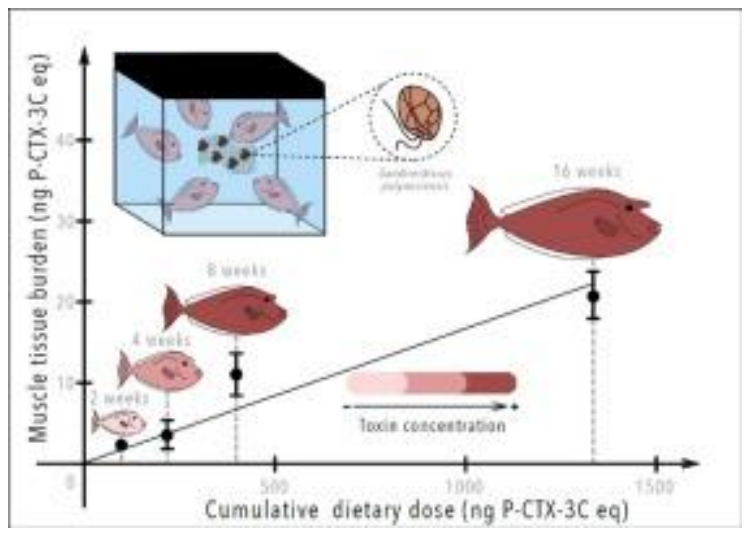

\section{Highlights}

An ecologically relevant procedure of dietary ciguatoxin transfer was developed. Fish consuming Gambierdiscus cells daily showed no signs of intoxication. Fish flesh contained CTX above thresholds for human illness in 2 weeks. Fish accumulated CTX continuously at a constant rate over 16 weeks. - Somatic growth dilution of CTX suggests slow-growing fish may be higher risk.

Keywords : Ciguatoxin, Bioaccumulation, Growth dilution, Trophic transfer, Herbivorous fish, Experimental model 


\section{INTRODUCTION}

43 Ciguatera poisoning (CP), the most common non-bacterial seafood-borne illness globally (Fleming et al., 44 2000; Friedman et al., 2008), is caused by the consumption of fish tissue containing ciguatoxins (CTXs; 45 Berdalet et al., 2016). CTXs are lipid-soluble, thermostable polycyclic ether molecules classed by geographical origin and differences in chemical structure. They include P-CTXs (Pacific Ocean), C-CTXs (Caribbean region) and I-CTXs (Indian Ocean). CTXs induce neurotoxic effects that result from binding to voltage-gated sodium channels $\left(\mathrm{Na}_{\mathrm{v}}\right)$ and potassium channels in excitable tissues (Dechraoui Bottein et al., 2006; Molgó et al., 1993; Nicholson and Lewis, 2006). CTXs are produced by species of benthic dinoflagellates of the genera Gambierdiscus (Adachi and Fukuyo, 1979; Yasumoto et al., 1977) and Fukuyoa (Gómez et al., 2015), which are distributed throughout tropical and subtropical coastal waters worldwide (Litaker et al., 2010). The presence of CTXs in the flesh of upper-trophic level fish, particularly one of the most toxic analogues, CTX1B (e.g. Lewis et al., 1991), is believed to result from consumption of Gambierdiscus cells (Bagnis et al., 1980; Yasumoto et al., 1977; Yasumoto et al., 1977) by herbivorous and omnivorous fish (Satake et al., 1996) and subsequent trophic transfer and toxifying biotransformation through the food web (Bienfang et al., 2013; Lehane and Lewis, 2000; Lewis and Holmes, 1993; Randall, 1958). After consumption of the dinoflagellates or other ciguatoxic prey, CTXs can bioaccumulate in select fish tissues such as liver (Yasumoto et al., 1977) and flesh, and concentrations may then successively increase up the fish food web (Lewis and Holmes, 1993). Despite the well-established threat to human health (Berdalet et al., 2016; Friedman et al., 2017), there are no established means of risk-assessment or resultant regulation of the fisheries and the market.

Tissue bioaccumulation of toxins and subsequent biomagnification is a central tenet of the trophic transfer 64 of CTXs underlying CP (Bienfang et al., 2013), yet evidence is primarily limited to the sampling and analysis of coral reef fish (e.g. Chan et al., 2011; Mak et al., 2013; reviewed by Yang et al., 2016) and several short-term feeding studies conducted in the laboratory (e.g. Helfrich and Banner, 1963; Ledreux et al., 2014; and in giant clams: Roué et al., 2016). Regional work has provided conflicting evidence, where 
some herbivorous fish have been found to contain high concentrations of CTXs in their flesh, comparable to those found in higher-trophic level fish (Chan et al., 2011; Darius et al., 2007; Gaboriau et al., 2014). Work examining the relationship of CTX concentrations and trophic level (as estimated by $\partial^{15} \mathrm{~N}$ ) in fish found weak or no correlations, depending on the CTX congener (Mak et al., 2013). An early laboratory study demonstrated transfer of toxin through feeding (Helfrich and Banner, 1963), but the herbivorous fish was fed ciguatoxic fish flesh, limiting the conclusions that can be drawn for natural food webs. In contrast, a recent study in which the omnivorous mullet Mugil cephalus was given food containing toxic cells of Gambierdiscus found that most toxin was eliminated within $24 \mathrm{~h}$ of feeding, and no toxin was accumulated over 9 cumulative feedings in 16 days. Moreover, fish showed strong signs of intoxication (Ledreux et al., 2014). Thus, until now, the mechanisms by which fish accumulate CTXs in their flesh at concentrations sufficient for intoxicating humans (>0.1 ng CTX1B g${ }^{-1}$ of fish; Lewis and Holmes 1993; Hossen et al. 2015) remain unclear (Ledreux et al., 2014; Yang et al., 2016) and poorly validated experimentally.

Correlating the dynamics of toxic Gambierdiscus on the reef with seafood toxicity and risk for CP involves predicting CTX concentrations in edible tissues in relation to time and environmental conditions (Llewellyn, 2010; Tester et al., 2010). This capability requires an understanding of the toxicokinetics of CTXs in fish and the development of mathematical models based on intake level, distribution, biotransformation and elimination. However, unknown ingested doses in the wild result in unknown absorption efficiencies and thus impair the ability to predict potential accumulation of flesh CTX concentrations. Current models of CTX trophic transfer are limited to a conceptual nature (e.g. CruzRivera and Villareal, 2006; Lewis and Holmes, 1993). Consequently, algal abundances on the reef are not easily associated with potential for CTX accumulation. Additional uncertainty may be introduced by high spatial heterogeneity and temporal variability in Gambierdiscus occurrence (reviewed by Cruz-Rivera and Villareal, 2006), interactions within reef trophic levels, or fish behaviour (e.g. migration and home ranges). This is particularly true for CTX, as blooms of Gambierdiscus spp. can occur and thus be 
consumed via macroalgal substrate throughout the year (Chateau-Degat et al., 2005; Chinain et al., 1999). After a disturbance, long-term (4-year) survey data indicates a $\sim 10$ month lag time before Gamberdiscus peak cell densities are observed (Chinain et al., 1999). The data shows an additional month passes before CTXs are detected in the flesh of herbivorous fish, and a subsequent $\sim 3$ month-lag before the maximum number of reported CP cases (Chateau-Degat et al., 2005; Clausing and Dechraoui Bottein, 2016). Thus, while short-term experiments (e.g. 9 feedings in 16 days: Ledreux et al., 2014; 48 h feeding trial: Roué et al., 2016) may provide important toxicological information, they may not reflect the true potential for toxin bioaccumulation in these species over time. Controlled experimental procedures using ecologicallyrelevant species and well-defined laboratory conditions are essential to better understand the processes underlying the accumulation of CTXs in fish flesh, knowledge that is required to predict the potential for $\mathrm{CP}$ along the food web. In this framework of seafood safety risk assessment, we developed an experimental model of CTX trophic transfer from the toxin-producing benthic dinoflagellate Gambierdiscus polynesiensis to an herbivorous coral reef fish, Naso brevirostris, over long-term dietary exposure.

\section{MATERIALS AND METHODS}

\subsection{Study species}

Cells of Gambierdiscus polynesiensis were obtained from mass cultures of the highly toxic strain TB92 (Tubuai, Australes archipelago, French Polynesia; Chinain et al., 2010; Chinain et al., 1999). Cultures were established in Fernbach flasks containing 1.25 L of f10k enriched natural seawater medium, inoculated at an initial cell density of $250-370$ cells $\mathrm{mL}^{-1}$, and grown at $26 \pm 1{ }^{\circ} \mathrm{C}$ under $100 \mu \mathrm{mol}$ photons $\mathrm{m}^{-2} \mathrm{~s}^{-1}$ (daylight fluorescent tubes) in a 12:12 h (light : dark) photoperiod with permanent aeration $\left(200 \mathrm{~L} \mathrm{hr}^{-1}\right)$. Cultures were harvested in their late exponential/early stationary growth phase and cells kept intact (as confirmed by light microscopy) at $-20^{\circ} \mathrm{C}$ until use for fish food preparation and toxin analysis. 
120 Naso brevirostris (Acanthuridae) are herbivorous and planktivorous species (trophic level 2.2-2.79;

121 Algaebase) inhabiting coral reefs throughout the Indo-Pacific. They eat primarily benthic algae, are 122 commonly implicated in CP, and CTXs have been detected in their flesh (Gaboriau et al., 2014; Mak et 123 al., 2013). Given its ecological relevance for CTX studies, availability from a supplier, and ability to be 124 kept in aquaria, $N$. brevirostris provides a relevant model for examining the processes of CTX entry into 125 the coral reef fish food web. Wild-caught juvenile $N$. brevirostris were obtained from a fish wholesaler 126 (Tropic Nguyen, France). Fish were caught with small nets directly on the reef in the Maldives and 127 acclimatized at least 15 days to aquarium conditions (seawater $25 \pm 0.5{ }^{\circ} \mathrm{C}$ and $38 \mathrm{psu}$ ) before shipment 128 (information provided by the supplier).

\subsection{Experimental Model}

131 To examine the processes of CTX trophic transfer from the microalgal producer into the fish food web,

132 we developed an experimental laboratory model of long-term CTX dietary exposure in fish under well-

133 defined conditions that consisted of feeding juvenile $N$. brevirostris with intact G. polynesiensis

134 embedded in a gelatin-based food. Toxin accumulation and resulting tissue burdens over time were 135 determined by measuring CTX levels in the flesh of fish after 2, 4, 8 and 16 weeks exposure. Although species of Gambierdiscus may also produce maitotoxins (MTXs), evidence that these toxins can accumulate in fish flesh is mixed (Kohli et al., 2014; Lewis, 2006a), and they have never been implicated

138 in human CP (Lewis, 2006b; Lewis and Holmes, 1993); thus, MTXs were not analysed in this study.

\section{Fish maintenance}

141 Prior to experimentation, fish were acclimated to laboratory conditions in an open-circuit 2000-L tank $142\left(150 \mathrm{~L} \mathrm{~h}^{-1}\right.$ of $0.45 \mu \mathrm{m}$ filtered seawater maintained at $25 \pm 0.5{ }^{\circ} \mathrm{C}$ and $\left.38 \mathrm{psu}\right)$ with a $12 \mathrm{~h}$ light: $12 \mathrm{~h}$ dark cycle. Fish were given a constant regimen of $10 \%$ body weight $\mathrm{d}^{-1}$ that initially consisted of lettuce and 
brine shrimp (Artemia salina, as a nutritional supplement) and gradually incorporated the gel food (Gelly

145 Belly ${ }^{\mathrm{TM}}$ Gel Food, Florida Aqua Farms, Inc., USA, preparation detailed below). Gelly Belly ${ }^{\mathrm{TM}}$ Gel Food 146 consists of a blend (in order of proportion) of microalgae, macroalgae, fish and krill meal, and vitamins 147 and minerals mixed with gelatin. PVC tubing provided structure to minimize stress (three $10 \mathrm{~cm} \times 20 \mathrm{~cm}$ 148 DxL tubes affixed in a pyramidal structure). After 2 months, the fish were consuming the gel food (6\% 149 body weight $\mathrm{d}^{-1}$ ) in less than 30 minutes.

150 Standards of animal welfare were carefully maintained throughout the experiment, and care was taken to 151 minimize handling to avoid physiological stress. Fish were euthanized by rapid chilling (Matthews and 152 Varga, 2012; Wilson et al., 2009).

\section{Gel food preparation}

155 Gel food was prepared by mixing the Gelly Belly ${ }^{\mathrm{TM}}$ dry powder with hot seawater $\left(\sim 70-80^{\circ} \mathrm{C}\right)$ at a ratio of approximately 2:3 g powder to $\mathrm{mL}$ seawater. The resulting paste was then spread onto nylon screen (2 $\mathrm{mm}$ mesh size) that served as a feeding support and was left to solidify at $-18{ }^{\circ} \mathrm{C}$ for at least $10 \mathrm{~min}$ (Figure 1). Cell-enriched gel food was prepared by adding hot seawater to a tube of frozen $G$. polynesiensis cells, vortexing to homogenize, and combining with the dry powder in plastic bags at the same water:powder ratio as above. The seawater temperature had no obvious effect on the integrity of the cells (microscopic observation, results not shown). The food was then mixed manually to ensure complete homogenization. The final concentration of $G$. polynesiensis in the food was 1,333 cells $\mathrm{g}^{-1} \mathrm{gel}_{\text {food. }}$

The stability of the Gambierdiscus-enriched gel food in seawater was assessed by measuring potential cell or CTX release from the food into the water over a period exceeding the time fish took to consume the food. Aliquots of $3 \mathrm{~g}$ gel food containing 1,633 cells $\mathrm{g}^{-1}$ G. polynesiensis were immersed in $5 \mathrm{~mL}$ of seawater for $0.5,1,1.5,2$ and $3 \mathrm{~h}(\mathrm{n}=3)$. As gel food contained a slightly higher quantity of cells than that fed to fish (1333 cells $\mathrm{g}^{-1}$ ), results provide a conservative estimate of potential toxin release. Seawater 
replicates were examined with light microscopy for the presence of cells and extracted using a C-18 solid

170 phase extraction (SPE) column (following Chinain et al., 2010; Darius et al., 2007, with minor

171 modification) before CTX assessment by receptor binding assay (RBA). Briefly, samples were loaded 172 onto $0.5 \mathrm{~g}, 6 \mathrm{~mL} \mathrm{C18} \mathrm{SPE}$ columns (Agilent Technologies, France) pre-conditioned with $2 \mathrm{~mL}$ methanol

$173(\mathrm{MeOH})$ followed by $5 \mathrm{~mL}$ Milli-Q. Samples were washed with $10 \mathrm{~mL}$ Milli-Q to remove salts and then 174 eluted with $4 \mathrm{~mL} 90 \%$ aqueous (aq) $\mathrm{MeOH}$. The column wash with 70\% aq $\mathrm{MeOH}$, which is used to 175 remove water soluble compounds such as MTXs, was omitted as MTXs do not cross react with CTXs. 176 Eluted samples were evaporated under nitrogen gas, resuspended in $100 \% \mathrm{MeOH}$, and stored at $-18{ }^{\circ} \mathrm{C}$ until CTX analysis with the RBA (Section 2.3).

\section{Fish exposure}

After acclimation, juvenile $N$. brevirostris (ranging 3.05-11.6 g and 4.5-9.5 $\mathrm{cm}$ in length) were sorted into size classes from which they were randomly distributed among five aquaria to achieve uniform size distribution across tanks $(n=5 ; 33.2 \pm 0.14$ g mean total biomass \pm SE per tank). Aquaria were 100-L with aerated, flow-through seawater $\left(100 \mathrm{~L} \mathrm{~h}^{-1}\right.$, all other conditions as above). To keep stress at a minimum, aquaria walls were covered with an opaque plastic coating, and PVC tubes provided habitat. At the time of distribution, three additional fish were euthanized, and tissue samples were collected as initial controls for CTX exposure (methods described at the end of this section).

Each aquarium was randomly assigned a time point $(2,4,8$ or 16 weeks exposure or the exposure control) at which to sacrifice all five fish in the aquarium (Table 1). Control fish were maintained throughout the 16-week duration and served both as behavioural controls for symptoms of intoxication and as analytical

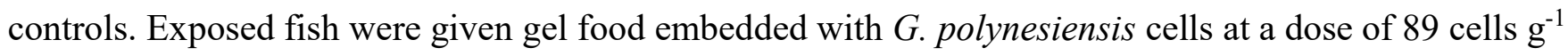
body weight daily, and control fish received gel food without cells. The cell concentration in the gel food was chosen based on field data of natural Gambierdiscus spp. bloom densities (Chateau-Degat et al.,

194 2005; Darius et al., 2007) and the quantity of food required by juvenile fish (5-10\% body weight $\left.\mathrm{d}^{-1}\right)$. 
196 Fish in all aquaria were fed five days per week at 09:00 at a constant proportion of 6\% of their biomass.

197 For the 8 and 16 week treatments, 3 and 4 feedings were missed due to laboratory closure, respectively, 198 resulting in 36 and 76 feedings instead of 40 and 80 (Table 1). Food quantities were adjusted every two to 199 four weeks based on estimated increases in biomass from a growth curve created by linear regression of 200 sacrificed fish weights at each time point (see results). Fish within a tank were fed together and observed 201 during the feeding period to confirm that each fish ate and that all food was consumed within a maximum 202 period of time (<30 min). As no hierarchical behaviour (e.g. dominance or territoriality around the food) 203 was observed prior to experimentation, the fish were assumed to eat a proportion of the food according to 204 their relative size. All fish were given thawed brine shrimp in the afternoon as a food complement to 205 achieve a daily ration of $10 \%$ body weight $\mathrm{d}^{-1}$.

At each time point, the individuals from the respective aquarium were collected and euthanized 8 hrs

208 post-feeding. Death was confirmed by the absence of respiratory movement. Fish were dissected 209 immediately to ensure the tissue integrity. The entirety of muscle tissue was collected, wet-weighed, and

210 stored at $-18{ }^{\circ} \mathrm{C}$ until toxin analysis. Control fish were sacrificed simultaneously with the 16 -week

211 treatment and were processed in an identical fashion.

\section{$213 \quad 2.3$ Toxin determination}

\section{Sample Extraction}

215 Cells of G. polynesiensis were extracted following Chinain et al. (1999a) with modification. Briefly, $216 \sim 50,000$ cells were extracted with 2 rounds each of $5 \mathrm{~mL} 100 \% \mathrm{MeOH}$ and $50 \%$ aq $\mathrm{MeOH}$ interspersed

217 with cell lysis by probe sonication in an ice bath (20 min initially; 2 min subsequently; Branson digital 218 sonifier) and centrifugation (5 min at $2000 \mathrm{rpm}$ ). Supernatants from each step were combined, adjusted to $21960 \%$ aq $\mathrm{MeOH}$ with Milli-Q water, and CTXs were isolated by 1:1 solvent-solvent separation with 
dichloromethane (DCM) in which the organic phase containing CTX was collected and evaporated to

221 dryness under a stream of nitrogen.

\section{2}

\section{3}

The muscle tissue of each fish (ranging $0.87-12.87 \mathrm{~g}$ across time-points; $4.81 \pm 0.65$ mean $\pm \mathrm{SEM}$ ) was extracted as previously described (Dechraoui et al., 2005; Ledreux et al., 2014; Yogi et al., 2011) with minor modifications. Tissues were cooked in Falcon tubes in a water bath at $70{ }^{\circ} \mathrm{C}$ for $15 \mathrm{~min}$, homogenized with a T-25 digital Ultra-Turrax (IKA Works, Germany) and extracted three times in acetone (3 $\mathrm{mL}: 1 \mathrm{~g}$ sample) with probe sonication ( $2 \mathrm{~min}$ ) and centrifugation. The combined supernatants were evaporated under a stream of nitrogen. Dried extracts were resuspended in $90 \%$ aq $\mathrm{MeOH}(5 \mathrm{~mL})$ and lipids were removed by three rounds of solvent-solvent separation with an equal volume n-hexane. A final 1:1 solvent-solvent separation (3x) between the aq $\mathrm{MeOH}$ phase (diluted to $60 \%$ with Milli-Q) and DCM isolated the organic phase containing CTXs. The organic phase was then evaporated under a stream of nitrogen, resuspended in $100 \% \mathrm{MeOH}$ to $10 \mathrm{~g}$ tissue equivalent (TE) $\mathrm{mL}^{-1}$, and stored at $-18{ }^{\circ} \mathrm{C}$ until toxin analysis. The gel food preparation was extracted following the same procedure as that for fish tissues with $20 \mathrm{~min}$ initial probe sonication to ensure cell lysis.

\section{Toxin analysis}

Composite CTX concentrations in G. polynesiensis cells and fish muscle extracts were quantified using a radioligand receptor binding assay (RBA) (Dechraoui Bottein and Clausing, 2017). This method is based on competitive displacement of tritiated brevetoxin $\left(\left[{ }^{3} \mathrm{H}\right] \mathrm{PbTx}-3\right)$ by the toxin standard (or CTX present in the sample extract) at their shared receptor on the voltage gated sodium channel (Dechraoui et al., 1999; Poli et al., 1986). The assay was carried out in a microplate format (IAEA-TECDOC-1729, 2013, with some modification) using a phosphate buffered saline buffer (PBST-Tween ${ }^{\circledR}$ ) with bovine serum albumin $\left(1 \mathrm{mg} \mathrm{mL}^{-1}\right), \mathrm{a}\left[{ }^{3} \mathrm{H}\right] \mathrm{PbTx}-3$ working solution (1 $\mathrm{nM}$ assay concentration), and a dilute membrane preparation of porcine brain homogenate $\left(0.8 \mathrm{mg}\right.$ protein $\left.\mathrm{mL}^{-1}\right)$. After incubation for $1 \mathrm{~h}$ at $4{ }^{\circ} \mathrm{C}$ and 
filtration with rinsing, the plate was incubated for $2 \mathrm{hr}$ in the dark with liquid scintillant (Optiphase,

246 PerkinElmer) before quantification of beta emissions in a beta counter (MicroBeta Plate Counter,

247 PerkinElmer). Toxin levels in samples (dilutions from $0.1-0.6 \mathrm{~g} \mathrm{TE} \mathrm{mL}^{-1}$ in assay, in triplicate) were

248 estimated against standard curves of CTX3C (Wako-Pure Chemicals, Osaka, Japan) and PbTx-3

249 (Latoxan, Rosam, France) and expressed as CTX3C equivalents. All samples were analysed in triplicate

250 in 2 to 4 independent RBA assays. A PbTx-3 QC check was run in triplicate on every assay to assess

251 inter-assay variability, requiring that the QC fall within 30\% of the stated value for assay acceptance.

252 Sample quantification was only completed on dilutions that fell on the linear portion of the curve and for

253 which the RSD of the triplicate CPM values was less than $30 \%$. This RSD requirement also assessed

254 intra-assay variability. The QC together with additional parameters of the standard curve including the

255 EC50, slope, and $100 \%$ binding (top of the curve) were systematically compared among trials to

256 determine assay performance and acceptability.

258 Sample toxin concentrations were evaluated against 4 parameter-sigmoidal standard curves fit using

259 GraphPad Prism version 6.0 (San Diego, USA). Differences between the control and all exposure

260 treatments were tested using bootstrapped multiple comparisons with a Bonferroni-corrected p-value ( $\alpha$ of

$2610.05 / 10=0.005)$ as the assumptions of factorial ANOVA were not met. Muscle toxin burden, the total

262 quantity of toxin contained in the organ, was calculated based on the muscle concentration and total

263 weight of the tissue collected. Regression analysis ( $\mathrm{x}, \mathrm{y}$ intercept set to zero) was used to assess

264 accumulation over time. All statistical analyses were performed using R software 3.0.1 (R Core Team, 265 2014).

267 The presence of ciguatoxin activity in the Gambierdiscus extract and selected fish muscle extracts was 268 also analysed using a cell based assay, the Neuro2a cytotoxicity assay (N2a-CBA) (Manger et al., 1993).

269 This assay also provides a sensitive measure of overall toxicity based on CTX properties that activate the 
voltage-gated sodium channel (Dechraoui et al., 2005) and was employed as a secondary detection

271 method following the protocol described in Roué et al. (2016).

273 The gel food preparation was analysed by LC-MS/MS (method adapted from Lewis et al., 2009) using an

274 LC system (UFLC XR Nexera, Shimadzu, Japan) coupled to a hybrid triple quadrupole-linear ion trap mass spectrometer (API-4000Qtrap, Sciex, CA, USA) equipped with a turboV® ion spray interface. LCMS/MS analysis was used to confirm the integrity of the CTX profile in the food as compared with the cells used for its preparation. A $1.8 \mu \mathrm{m}$ C18 Zorbax Eclipse plus column $(50 \cdot 2.1 \mathrm{~mm}$, Agilent technologies, CA, USA) was employed at $40{ }^{\circ} \mathrm{C}$ and eluted at $400 \mu 1 \min ^{-1}$ using a linear gradient of eluent A (water) and eluent $\mathrm{B}(\mathrm{MeOH})$. Both eluents contained $2 \mathrm{mM}$ ammonium formiate and $50 \mathrm{mM}$ formic acid. The elution gradient ran from 78 to $88 \%$ B over 10 min and was held for 4 min before reequilibration during $5 \mathrm{~min}$. Mass spectrometry detection was operated in positive mode using Multiple Reaction Monitoring (MRM). The pseudomolecular ions $\left[\mathrm{M}+\mathrm{NH}_{4}\right]^{+}$and $[\mathrm{M}+\mathrm{H}]^{+}$were selected as precursor ions. The ions resulting in the successive losses of $\mathrm{NH}_{4}$ and/or water molecules were selected as product ions. Data quantification was performed from a linear calibration curve of CTX3C standard (Wako-Pure Chemicals, Osaka, Japan) using Analyst software (Sciex, CA, USA). The chromatogram profile was completed by injecting a mix of standards (CTX1B, 49-epiCTX3C [Р-CTX3B] and CTX3C, all three provided by the Institut Louis Malardé) in the sequence.

\section{RESULTS AND DISCUSSION}

\subsection{Rates and relevancy of experimental CTX exposure}

Toxin contents in G. polynesiensis cell extracts were estimated against CTX3C standard curves in four independent assays and expressed as CTX3C equivalents (equiv). In each assay, dilutions of cell extract at 7 concentrations ranging from 2 to 2100 cell $\mathrm{mL}^{-1}$ produced a full sigmoidal dose-response curve (Figure 2A.; mean $\mathrm{IC}_{50}=148.4$ cells $\mathrm{mL}^{-1}$ ). Using the $\mathrm{IC}_{50}$ (inhibitory concentration at $50 \%$ ) from the 
standard curve and that from the cell extract curve in each assay, the average toxin content per cell was

296 estimated to be $4.5 \mathrm{pg} \mathrm{CTX3C} \mathrm{equiv} \mathrm{cell}{ }^{-1}$. Subsequent analysis with the N2a CBA confirmed cell toxin 297 concentrations $\left(3.6 \mathrm{pg}\right.$ CTX3C equiv cell $\left.{ }^{-1}\right)$.

299 LC-MS/MS analysis of an extract of Gambierdiscus-embedded gel food (at 1333 cells $\mathrm{g}^{-1}$, as prepared for 300 the dietary exposure) confirmed toxin levels and toxin stability during the preparation process (3.3 pg 301 CTX3C equiv. cell ${ }^{-1}$ ). The dominant CTX analogue extracted was CTX3C, followed by 49-epiCTX3C 302 (Figure 2B), which matches the CTX profile previously determined for the TB92 strain of $G$. 303 polynesiensis (Chinain et al., 2010).

The gel food stability test showed no release of toxin into the surrounding seawater during $3 \mathrm{~h}$ immersion; at all time points, CTX concentrations in the seawater extracts were found to be below the limit of detection of the RBA (LOQ: $1.4610^{-10} \mathrm{~g}$ CTX3C equiv $\mathrm{mL}^{-1}$ seawater, equivalent to $2 \%$ of the total toxin added). Furthermore, light microscopy revealed no visible cells in the seawater. By comparison, the gel food given to exposed fish contained lower cell concentrations $\left(1,333\right.$ cells $\mathrm{g}^{-1}$ gel food vs $1,633{\text { cells } \mathrm{g}^{-1}}^{-1}$ in the stability assay), was immersed in a much larger volume of seawater (100 L tanks compared to $5 \mathrm{~mL}$ in the assay), and was consumed in less than $30 \mathrm{~min}$. Thus the food stability results indicate that any toxin potentially released into the water of the aquaria can be considered negligible. Moreover, the fish were maintained in open seawater circulation; thus, any toxin released from the food or excreted out of the body during the experiment would be rapidly flushed, ensuring that fish exposure to CTX was limited to the dietary pathway, not via the respiratory pathway.

317 Given the cell content in the food (1,333 cells G. polynesiensis $\left.\mathrm{g}^{-1}\right)$ and the ration provided ( $0.06 \mathrm{~g}$ food $\mathrm{g}$ 318 fish $\left.^{-1} \mathrm{~d}^{-1}\right)$, the fish received an estimated daily dose of $0.4 \mathrm{ng} \mathrm{CTX} 3 \mathrm{C}$ equiv $\mathrm{g} \mathrm{fish} \mathrm{s}^{-1}$. At the onset of the 319 experiment, where the average body weight per fish across all treatments was $6.6 \pm 0.4 \mathrm{~g}$ SEM $(n=25)$, 
this corresponded to an average quantity of $\sim 2.7 \mathrm{ng} \mathrm{CTX3C} \mathrm{equiv} \mathrm{fish}{ }^{-1} \mathrm{~d}^{-1}$, although actual quantities

321 consumed were assumed to vary with differences in size among individuals within a tank. The quantity of

322 cells that we chose for fish exposure reflects cell densities to which fish are likely exposed when feeding

323 on macroalgal substrate throughout the year. Previous field surveys have shown that bloom densities

324 commonly reach 5,000 cells g-1 macroalgae in French Polynesia (Chinain et al., 1999b) or 20,000-50,000

325 cells $\mathrm{g}^{-1}$ in the Caribbean (Cruz-Rivera and Villareal, 2006), and are frequently maintained at densities

326 greater than 1,000 cells g$^{-1}$ throughout the year (e.g. Chateau-Degat et al., 2005; Chinain et al., 1999b).

327 Occasional cell densities as high as 1,000,000 cells $\mathrm{g}^{-1}$ have been reported in both the Atlantic and Pacific

328 (Litaker et al., 2010). The dietary intake of CTX in the field, however, depends on individual

329 Gambierdiscus species' toxicity, which varies widely both within (Chinain et al., 1999; Lewis et al.,

330 2016; Pisapia et al., 2017) and among (Dai et al., 2017; Litaker et al., 2010) ocean basins (ranging from

331 non-toxic or fg cell $^{-1}$ up to $1.5 \mathrm{pg} \mathrm{CTX} 3 \mathrm{C}$ equiv cell $^{-1}$ for the Atlantic species $G$. excentricus: Pisapia et

332 al., 2017 and 11.9 pg CTX3C equiv cell ${ }^{-1}$ for the Pacific G. polynesiensis: Chinain et al., 2010).

\subsection{Fish behaviour}

344 Exposed fish exhibited no abnormal behaviour during the experiment, including signs of intoxication such as rapid gill movement or erratic swimming or fin movement. Moreover, fish showed no signs of 
stress during experimentation, either in general or in comparison with control fish. There was, however, 347 one mortality apparently unrelated to exposure (the one fish was found outside of the tank; 8 weeks 348 treatment, $\mathrm{n}=4)$.

350 The absence of intoxication in the exposed fish indicated that the given dose was relevant to naturally 351 occurring exposure on the reef. The absence of signs of intoxication in wild fish found with high CTX 352 concentrations (e.g. from human intoxication events or from field surveys) has long confounded understanding of how this potent toxin can accumulate to the high levels at which it is naturally found (Lehane and Lewis, 2000). This is particularly perplexing as the toxin has been shown to bind to fish brain, muscle and heart $\mathrm{Na}_{\mathrm{v}}$ in laboratory tests (Dechraoui Bottein et al., 2006), cause fish mortality through water exposure (Lewis, 1992), and result in developmental toxicity in finfish (Colman et al., 2004; Yan et al., 2017). Our results provide tentative support of the hypothesis of Banner et al. (1963) that naturally exposed species have developed some form of resistance, whether by physiological mechanisms or genetic adaptations, such as the production of CTX storage proteins that render the toxin non-bioavailable (e.g. skeletal muscle soluble proteins Hahn et al., 1992). However, early experiments feeding ciguatoxic fish flesh to species potentially encountering CTX in the wild (grouper, snapper and wrasse) did result in behavioural abnormalities, although the CTX dose administered was not known/reported (Davin Jr. et al., 1986; Davin Jr et al., 1988). More recently, Ledreux et al. (2014) also found that a mullet (Mugil cephalus) showed extreme signs of intoxication after exposure to similar CTX doses as in this study (0.3 vs $0.4 \mathrm{ng} \mathrm{g}^{-1}$ fish) using the same strain of G. polynesiensis (TB92). However, the concentration of cells in the food was nearly 10 -fold higher (13,000 vs 1,333 cells $\mathrm{g}^{-1}$ food), and the species of mullet used were native to streams in the Southeast of the USA where they are unlikely to be exposed to CTX. Thus, toxic response to ingestion of CTXs may vary among fish; it remains unclear if fish intoxication is a function of adaptations for resistance or of prey type or feed concentration, or a combination of these factors. 


\section{3}

Analysis of fish muscle tissue by RBA revealed that fish had accumulated significant quantities of CTXs within 2 weeks (1.2 ng CTX3C equiv g ${ }^{-1}$ TE in 10 feedings; Figure 4A; Table 2) at values above the USFDA recommended action level of $0.01 \mathrm{ng} \mathrm{g}^{-1} \mathrm{CTX} 1 \mathrm{~B}$ equiv [corresponding to a 10-fold safety margin on the risk value of $0.1 \mathrm{ng} \mathrm{g}^{-1}$ proposed by Lewis (1991) after analysis by mouse bioassay of fish remnants involved in ciguatera cases]. With a toxic equivalency factor (TEF) of 0.2 for CTX3C (EFSA Panel on Contaminants in the Food Chain, 2010), this latter value would correspond to $0.5 \mathrm{ng}$ CTX3C equiv $\mathrm{g}^{-1}$. After 10 additional doses of Gambierdiscus enriched food (4 weeks treatment), toxin concentrations remained similar, but by 8 weeks (37 feedings), muscle toxin concentrations had increased $\sim 300 \%$, where they remained through 16 weeks of exposure (Table 2). The presence of CTXs in the muscle of exposed fish was confirmed by N2a CBA; however, definite quantification was limited by sample availability (results not shown). No detectable amounts of toxin were found in either initial or experimental controls. Overall, our results are consistent with field data indicating that CTX appears in herbivorous fish less than one month after high Gambierdiscus densities appear on the reef (Clausing and Dechraoui Bottein, 2016). Moreover, they are also in accordance with CTX concentrations found in wildcaught $N$. brevirostris (1-7 ng CTX3C equiv $\mathrm{g}^{-1}$ flesh (Gaboriau et al., 2014), and, taken with the lack of observed signs of intoxication, confirm that $N$. brevirostris is an appropriate experimental model.

As fish continued to grow throughout the duration of the experiment $\left(\sim 1.3 \mathrm{~g} \mathrm{wk}^{-1}\right)$, the quantity of food given was adjusted every 2 to 4 weeks to remain at a roughly constant dose by biomass. An examination of toxin tissue burden in muscle revealed a linear increase with toxin intake (i.e. dose; linear regression, $p$ $<0.0001$ : Figure 4B; Table 2), where the rate of dietary assimilation (percent ingested toxin retained in the tissue) was relatively constant at $\sim 2 \%$. Consequently, the rate of accumulation $\left(\sim 1.4 \mathrm{ng} \mathrm{wk}^{-1}\right)$ also stayed positive and constant. However, the increase in muscle mass was not constant as the fish grew, causing somatic growth dilution that masked increasing toxin tissue content and resulted in apparent saturation in muscle toxin concentrations after 8 weeks (Figure 4A). Indeed, in fish sacrificed at 2 weeks, 
muscle tissue contributed $19.8 \pm 1.2 \%$ (mean \pm SEM) of the total body weight $(7.9 \pm 0.65 \mathrm{~g}$ per individual). At 4 weeks, muscle tissue contribution to total body weight was still at $20.6+/-1.56 \%$ but by

\section{0}

8 weeks had slightly increased to $23.9+/-0.70 \%$. After 16 weeks, in contrast, muscle was $32.3 \pm 4.0 \%$ of total body weight ( $26.7 \pm 2.5 \mathrm{~g}$ per individual). These data suggest that fish that grow large faster may have lower CTX concentrations than slow-growing fish due to somatic growth dilution (Yang et al., 2016). Bio-dilution of chemical toxins (e.g. organic chemicals, mercury) is well-established in fish species (Clark et al., 1990; Ward et al., 2010) and has been suggested for brevetoxins in turtles (Perrault et al., 2014). Yet, fisheries regulations in regions with endemic ciguatera are often based on size (e.g. Chan, 2015a; Clua et al., 2011; reviewed by Yang et al., 2016) where larger fish of the same species are assumed to contain higher CTX concentrations in the flesh (Chan, 2015b; Lehane and Lewis, 2000; Lewis and Holmes, 1993; Oshiro et al., 2010). Our results indicate that size alone may not be a reliable indicator of ciguatoxicity. In fact, growth dilution may provide a mechanism for the contradictory findings on the relationship between size and CTX concentrations in field sampled fish (Darius et al., 2007; Dechraoui et al., 2005; Gaboriau et al., 2014; Mak et al., 2013; O’Toole et al., 2012), particularly as growth rates are known to vary among coral reef fish families $\left(0.2-1.0 \mathrm{~cm} \mathrm{yr}^{-1}\right.$; McClanahan, 2015). However, as fish grow more slowly after reaching maturity or during reproductive stage (Hutchings, 1993; Lester et al., 2004), very old fish are likely to be high risk if they are sessile in endemic areas.

The final concentration of toxins accumulated in the flesh of fish depends not only on dietary intake and growth, but also on variation in physiological processes among conspecifics that may influence CTX toxicokinetics. In our experimental procedure, fish were maintained and fed in treatment groups; the development of a similar, but individual-based approach in which each fish is fed separately and reweighed may provide a means to determine potential intraspecific variability (although the destructive sampling used for tissue toxin detection precludes successive toxin measurements in individual fish). In nature, both dietary exposure and fish physiology will vary significantly due to irregularity in Gambierdiscus distribution, bloom intensity and toxicity (Chinain et al., 1999; Lewis et al., 2016; Pisapia 
et al., 2017), as well as species interactions and environmental conditions. Given these known sources of variability, this laboratory procedure could be used to test scenarios and parameterize models for identified ciguatera-prone areas in which the habitat characteristics, fish populations, and Gambierdiscus bloom dynamics are well-known and actively monitored.

In our study, as the dose of toxin consumed and the growth rates were both known and constant over time, the roughly constant rate of accumulation found in the muscle (Figure 4B) relates to a balance between absorption and depuration efficiencies. The degree of metabolization of CTXs as they pass through digestion (Lewis et al., 1991; Murata et al., 1990) is a key factor affecting their storage in and/or elimination from fish (Lewis and Holmes, 1993). In general, the quantity of oxidized forms of CTXs increase with metabolization and thus with trophic level (Lewis, 2000; Lewis and Holmes, 1993), with an accompanying increase in potency associated with greater polarity (Dechraoui et al., 1999; Yogi et al., 2011). It has been suggested that increasing polarity with transformation in fish may be a mechanism to facilitate depuration (Lewis and Sellin, 1992). The Gambierdiscus species used in our study, G. polynesiensis, has been shown to contain primarily CTX3C (40-50\%), followed by 49-epiCTX3C and CTX4A, and, in small quantities, CTX4B (Chinain et al., 2010). Herbivorous fish in the Pacific, however, and specifically acanthurids, may also contain more metabolized and thus more potent analogues. These CTXs include significant quantities of CTX4B (Satake et al., 1996) and lesser amounts of CTX1B, the biotransformation end-product, as well as 52-epi-54-deoxyCTX1B (P-CTX2) and 54-deoxyCTX1B (PCTX3), both biotransformation intermediates (Mak et al., 2013). In herbivorous fish with acidic digestive tracts, for example, acid-catalysed spiro-isomerisation may affect the production of polar forms of CTX (Lewis and Holmes, 1993; Murata et al., 1990) and thus may affect rates of detoxification and depuration.

Overall, these processes of metabolization and depuration remain to be determined in herbivorous fish. The procedure presented here could be adapted to follow the tissue distribution of CTX among body compartments within an individual and compared among fish after varying periods of exposure and 
depuration. Moreover, our model of CTX trophic transfer in herbivorous fish is consistent with what we

451 understand of this process in the wild; the natural means of dietary exposure to relevant doses in

452 appropriate model species, together with the resulting general health and lack of behavioural signs of

453 intoxication as well as the timeline of toxin accumulation set this experimental method apart from past

454 laboratory exposure studies (Davin Jr. et al., 1986; Davin Jr et al., 1988; Helfrich and Banner, 1963;

455 Ledreux et al., 2014). Thus, the model developed here can be useful to advance understanding of

456 ciguatoxin kinetics both within individuals and among trophic levels and can support development of

457 predictive models of risk assessment for well-characterized and regularly monitored reef systems.

\section{ACKNOWLEDGEMENTS}

461 The experimental work was conducted at the IAEA-Environment Laboratories in Monaco. The

462 International Atomic Energy Agency is grateful to the Government of the Principality of Monaco for the 463 support provided to its Environment Laboratories. LC-MS/MS analysis was carried out at the

464 PHYCOTOXINS laboratory of the Atlantic Centre of Ifremer in Nantes, France.

This work was conducted in the framework of two agreements signed between the IAEA-Environment

Laboratories and the Institut Louis Malardé in French Polynesia: 1. Agreement for research collaboration on the impacts of harmful algal blooms and contaminants on marine ecosystems and seafood safety; 2. Agreement concerning extra budgetary contribution for the experimental assessment of ciguatera toxins' toxicokinetics and dynamics in fish.

The authors wish to thank the countries of France and French Polynesia for providing funding support as part of the research program entitled CAractérisation et gestion des RIsques environnementaux et 
474 Sanitaires liés au développement du phyTOplancton ciguatérigène en Polynésie française ( CARISTO-

475 Pf, Contrat de Projets 2016-2020)

476

477 The authors are also grateful to Lucile Bottein, who designed and executed the graphic abstract, and to

478 André Ung and Jérome Viallon for their technical assistance in maintaining Gambierdiscus cultures and 479 the N2a-CBA analysis, respectively. Finally, the authors are thankful for helpful discussions with Marc 480 Metian as well as for constructive comments of the anonymous reviewers. 


\section{REFERENCES}

Adachi, R., Fukuyo, Y., 1979. The thecal structure of a marine toxic dinoflagellate Gambierdiscus toxicus gen. et sp. nov. collected in a ciguatera-endemic area. Bull. Japanese Soc. Sci. Fish. 45, 67-71.

Bagnis, R., Chanteau, S., Chungue, E., Hurtel, J.M., Yasumoto, T., Inoue, A., 1980. Origins of ciguatera fish poisoning: a new dinoflagellate, Gambierdiscus toxicus Adachi and Fukuyo, definitively involved as a causal agent. Toxicon 18, 199-208. https://doi.org/10.1016/0041-0101(80)90074-4

Banner, A., Helfrich, P., Yoshida, T., 1963. Research on ciguatera in the tropical Pacific. Proc. Gulf Caribb. Fish. Inst. 16, 84-98.

Berdalet, E., Fleming, L.E., Gowen, R., Davidson, K., Hess, P., Backer, L.C., Moore, S.K., Hoagland, P., Enevoldsen, H., 2016. Marine harmful algal blooms, human health and wellbeing: challenges and opportunities in the 21st century. J. Mar. Biol. Assoc. United Kingdom 96, 61-91. https://doi.org/10.1017/S0025315415001733

Bienfang, P.K., Trapido-Rosenthal, H., Laws, E.A., 2013. Bioaccumulation/Biomagnifications in Food Chains, in: Environmental Toxicology. Springer, pp. 35-69.

Chan, T.Y.K., 2015a. Ciguatera fish poisoning in East Asia and southeast Asia. Mar. Drugs 13, 34663478.

Chan, T.Y.K., 2015b. Review article: Ciguatoxic potential of brown-marbled grouper in relation to fish size and geographical origin. Am. J. Trop. Med. Hyg. 93, 1117-1121. https://doi.org/10.4269/ajtmh.15-0434

Chan, W.H., Mak, Y.L., Wu, J.J., Jin, L., Sit, W.H., Lam, J.C.W., de Mitcheson, Y.S., Chan, L.L., Lam, P.K.S., Murphy, M.B., 2011. Spatial distribution of ciguateric fish in the Republic of Kiribati. Chemosphere 84, 117-123.

Chateau-Degat, M.L., Chinain, M., Cerf, N., Gingras, S., Hubert, B., Dewailly, É., 2005. Seawater temperature, Gambierdiscus spp. variability and incidence of ciguatera poisoning in French Polynesia. Harmful Algae 4, 1053-1062. https://doi.org/10.1016/j.hal.2005.03.003

Chinain, M., Darius, H.T., Ung, A., Cruchet, P., Wang, Z., Ponton, D., Laurent, D., Pauillac, S., 2010. Growth and toxin production in the ciguatera-causing dinoflagellate Gambierdiscus polynesiensis (Dinophyceae) in culture. Toxicon 56, 739-750. https://doi.org/10.1016/j.toxicon.2009.06.013

Chinain, M., Faust, M.A., Pauillac, S., 1999a. Morphology and molecular analyses of three toxic species of Gambierdiscus (Dinophyceae): G. pacificus, sp. nov., G. australes, sp. nov., and G. polynesiensis, sp. nov. J. Phycol. 35, 1282-1296.

Chinain, M., Germain, M., Deparis, X., Pauillac, S., Legrand, A.M., 1999b. Seasonal abundance and toxicity of the dinoflagellate Gambierdiscus spp.(Dinophyceae), the causative agent of ciguatera in Tahiti, French Polynesia. Mar. Biol. 135, 259-267.

Clark, K.E., Gobas, F. a. P.C.F.A.P.C., Mackay, D., 1990. Model of organic chemical uptake and clearance by fish from food and water. Environ. Sci. Technol. 24, 1203-1213. https://doi.org/10.1021/es00078a008

Clausing, R.J., Dechraoui Bottein, M.-Y., 2016. Practical sampling guidance for determination of ciguatoxin in fish, in: Reguera, B., Alonso, R., Moreira, A., Méndez, S., Dechraoui-Bottein, M.-Y. (Eds.), Guide for Designing and Implementing a Plan to Monitor Toxin-Producing Microalgae. Intergovernmental Oceanographic Commission (IOC) of UNESCO and International Atomic Energy Agency (IAEA), Paris and Vienna, pp. 51-63.

Clua, E., Brena, P.F., Lecasble, C., Ghnassia, R., Chauvet, C., 2011. Prevalence and proposal for costeffective management of the ciguatera risk in the Noumea fish market, New Caledonia (South Pacific). Toxicon 58, 591-601. 
Colman, J.R., Dechraoui, M.Y.B., Dickey, R.W., Ramsdell, J.S., 2004. Characterization of the developmental toxicity of Caribbean ciguatoxins in finfish embryos. Toxicon 44, 59-66. https://doi.org/10.1016/j.toxicon.2004.04.007

Cruz-Rivera, E., Villareal, T.A., 2006. Macroalgal palatability and the flux of ciguatera toxins through marine food webs. Harmful Algae. https://doi.org/10.1016/j.hal.2005.09.003

Dai, X., Mak, Y.L., Lu, C.K., Mei, H.H., Wu, J.J., Lee, W.H., Chan, L.L., Lim, P.T., Mustapa, N.I., Lim, H.C., Wolf, M., Li, D., Luo, Z., Gu, H., Leaw, C.P., Lu, D., 2017. Taxonomic assignment of the benthic toxigenic dinoflagellate Gambierdiscus sp. type 6 as Gambierdiscus balechii (Dinophyceae), including its distribution and ciguatoxicity. Harmful Algae 67, 107-118. https://doi.org/10.1016/j.hal.2017.07.002

Darius, H.T., Ponton, D., Revel, T., Cruchet, P., Ung, A., Tchou Fouc, M., Chinain, M., 2007. Ciguatera risk assessment in two toxic sites of French Polynesia using the receptor-binding assay. Toxicon 50, 612-626. https://doi.org/10.1016/j.toxicon.2007.05.007

Davin Jr., W.T., Kohler, C.C., Donald, R., 1986. Effects of ciguatera toxins on the bluehead. Trans. Am. Fish. Soc. 115, 37-41. https://doi.org/10.1577/1548-8659(1986)115

Davin Jr, W.T., Kohler, C.C., Tindall, D.R., 1988. Ciguatera toxins adversely affect piscivorous fishes. Trans. Am. Fish. Soc. 117, 374-384.

Dechraoui, M.-Y.B., Tiedeken, J.A., Persad, R., Wang, Z., Granade, H.R., Dickey, R.W., Ramsdell, J.S., 2005. Use of two detection methods to discriminate ciguatoxins from brevetoxins: Application to great barracuda from Florida Keys. Toxicon 46, 261-270.

Dechraoui, M.Y., Naar, J., Pauillac, S., Legrand, A.M., 1999. Ciguatoxins and brevetoxins, neurotoxic polyether compounds active on sodium channels. Toxicon. https://doi.org/10.1016/S00410101(98)00169-X

Dechraoui Bottein, M.-Y., Clausing, R.J., 2017. Receptor binding assay for the analysis of marine toxins: detection and mode of action, in: Diogène, J., Campàs, M. (Eds.), CAC: Recent Advances in the Analysis of Marine Toxins. Elsevier, in press, pp. 277-301.

Dechraoui Bottein, M.Y., Wacksman, J.J., Ramsdell, J.S., 2006. Species selective resistance of cardiac muscle voltage gated sodium channels: Characterization of brevetoxin and ciguatoxin binding sites in rats and fish. Toxicon. https://doi.org/10.1016/j.toxicon.2006.07.032

EFSA Panel on Contaminants in the Food Chain, 2010. Scientific Opinion on marine biotoxins in shellfish--Emerging toxins: Ciguatoxin group. EFSA J. 8, 1627-1665. https://doi.org/10.2903/j.efsa.2010.1627

Fleming, L., Dewailly, E., Baden, D.G., 2000. The epidemiologic of marine harmful algal blooms. Epidemiology 11, 143.

Friedman, M.A., Fernandez, M., Backer, L.C., Dickey, R.W., Bernstein, J., Schrank, K., Kibler, S., Stephan, W., Gribble, M.O., Bienfang, P., Bowen, R.E., Degrasse, S., Quintana, H.A.F., Loeffler, C.R., Weisman, R., Blythe, D., Berdalet, E., Ayyar, R., Clarkson-Townsend, D., Swajian, K., Benner, R., Brewer, T., Fleming, L.E., 2017. An updated review of ciguatera fish poisoning: Clinical, epidemiological, environmental, and public health management. Mar. Drugs 15. https://doi.org/10.3390/md15030072

Friedman, M.A., Fleming, L.E., Fernandez, M., Bienfang, P., Schrank, K., Dickey, R., Bottein, M.-Y., Backer, L., Ayyar, R., Weisman, R., others, 2008. Ciguatera fish poisoning: treatment, prevention and management. Mar. Drugs 6, 456-479.

Gaboriau, M., Ponton, D., Darius, H.T., Chinain, M., 2014. Ciguatera fish toxicity in French Polynesia: Size does not always matter. Toxicon $84,41-50$.

Gómez, F., Qiu, D., Lopes, R.M., Lin, S., 2015. Fukuyoa paulensis gen. et sp. nov., a new genus for the 
globular species of the dinoflagellate Gambierdiscus (Dinophyceae). PLoS One 10, e0119676.

Hahn, S.T., Capra, M.F., Walsh, T.P., 1992. Ciguatoxin-protein association in skeletal muscle of Spanish mackerel (Scomberomorus commersoni). Toxicon 30, 843-852. https://doi.org/10.1016/00410101(92)90382-F

Helfrich, P., Banner, A.H., 1963. Experimental induction of ciguatera toxicity in fish through diet. Nature 197, 1025-1026.

Hossen, V., Soliño, L., Leroy, P., David, E., Velge, P., Dragacci, S., Krys, S., Flores Quintana, H., Diogène, J., 2015. Contribution to the risk characterization of ciguatoxins: LOAEL estimated from eight ciguatera fish poisoning events in Guadeloupe (French West Indies). Environ. Res. 143, 100108. https://doi.org/10.1016/j.envres.2015.09.014

Hutchings, J.A., 1993. Adaptive life histories effected by age-specific survival and growth rate. Ecology 74, 673-684. https://doi.org/10.2307/1940795

IAEA-TECDOC-1729, 2013. Detection of harmful algal toxins using the radioligand receptor binding assay: A manual of methods. Vienna. https://doi.org/10.13140/2.1.2586.1122

Kohli, G.S., Papiol, G.G., Rhodes, L.L., Harwood, D.T., Selwood, A., Jerrett, A., Murray, S.A., Neilan, B.A., 2014. A feeding study to probe the uptake of Maitotoxin by snapper (Pagrus auratus). Harmful Algae 37, 125-132. https://doi.org/10.1016/j.hal.2014.05.018

Ledreux, A., Brand, H., Chinain, M., Bottein, M.Y.D., Ramsdell, J.S., 2014. Dynamics of ciguatoxins from Gambierdiscus polynesiensis in the benthic herbivore Mugil cephalus: Trophic transfer implications. Harmful Algae 39, 165-174. https://doi.org/10.1016/j.hal.2014.07.009

Lehane, L., Lewis, R.J., 2000. Ciguatera: recent advances but the risk remains. Int. J. Food Microbiol. 61, 91-125.

Lester, N.P., Shuter, B.J., Abrams, P.A., 2004. Interpreting the von Bertalanffy model of somatic growth in fishes: the cost of reproduction. Proc. R. Soc. B 271, 1625-1631. https://doi.org/10.1098/rspb.2004.2778

Lewis, R.J., 2006a. Ciguatera: Australian perspectives on a global problem. Toxicon. https://doi.org/10.1016/j.toxicon.2006.07.019

Lewis, R.J., 2006b. Ciguatera: Australian perspectives on a global problem. Toxicon 48, 799-809. https://doi.org/10.1016/j.toxicon.2006.07.019

Lewis, R.J., 2000. The changing face of ciguatera. Toxicon 39, 97-106. https://doi.org/10.1016/S00410101(00)00161-6

Lewis, R.J., 1992. Ciguatoxins are potent ichthyotoxins. Toxicon 30, 207-2011.

Lewis, R.J., Holmes, M.J., 1993. Origin and transfer of toxins involved in ciguatera. Comp. Biochem. Physiol. Part C Comp. 106, 615-628. https://doi.org/10.1016/0742-8413(93)90217-9

Lewis, R.J., Inserra, M., Vetter, I., Holland, W.C., Hardison, D.R., Tester, P.A., Litaker, R.W., 2016. Rapid extraction and identification of maitotoxin and ciguatoxin-like toxins from Caribbean and Pacific Gambierdiscus using a new functional bioassay. PLoS One 11. https://doi.org/10.1371/journal.pone.0160006

Lewis, R.J., Sellin, M., 1992. Multiple ciguatoxins in the flesh of fish. Toxicon 30, 915-919. https://doi.org/10.1016/0041-0101(92)90390-Q

Lewis, R.J., Sellin, M., Poli, M.A., Norton, R.S., MacLeod, J.K., Sheil, M.M., 1991. Purification and characterization of ciguatoxins from moray eel (Lycodontis javanicus, Muraenidae). Toxicon 29, $1115-1127$.

Lewis, R.J., Yang, A., Jones, A., 2009. Rapid extraction combined with LC-tandem mass spectrometry (CREM-LC/MS/MS)for the determination of ciguatoxins in ciguateric fish flesh. Toxicon 54, $62-66$. 
Litaker, R.W., Vandersea, M.W., Faust, M.A., Kibler, S.R., Nau, A.W., Holland, W.C., Chinain, M., Holmes, M.J., Tester, P.A., 2010. Global distribution of ciguatera causing dinoflagellates in the genus Gambierdiscus. Toxicon. https://doi.org/10.1016/j.toxicon.2010.05.017

Llewellyn, L.E., 2010. Revisiting the association between sea surface temperature and the epidemiology of fish poisoning in the South Pacific: Reassessing the link between ciguatera and climate change. Toxicon 56, 691-697.

Mak, Y., Wai, T., Murphy, M., Chan, W., Wu, J., Lam, J., Chan, L., Lam, P., 2013. Pacific ciguatoxins in food web components of coral reef systems in the Republic of Kiribati. Environ. Sci. Technol. 47, 14070-14079.

Manger, R.L., Leja, L.S., Lee, S.Y., Hungerford, J.M., Wekell, M.M., 1993. Tetrazolium-based cell bioassay for neurotoxins active on voltage-sensitive sodium channels: Semiautomated assay for saxitoxins, brevetoxins, and ciguatoxins. Anal. Biochem. 214, 190-194. https://doi.org/10.1006/abio.1993.1476

Matthews, M., Varga, Z.M., 2012. Anesthesia and euthanasia in zebrafish. ILAR J. 53, 192-204. https://doi.org/10.1093/ilar.53.2.192

McClanahan, T.R., 2015. Resilience in reef fish communities, in: Mora, C. (Ed.), Ecology of Fishes on Coral Reefs. Cambridge University Press, pp. 183-190. https://doi.org/10.1016/00220981(93)90022-G

Molgó, J., Shimahara, T., Legrand, A.M., 1993. Ciguatoxin, extracted from poisonous morays eels, causes sodium-dependent calcium mobilization in NG108-15 neuroblastoma $\times$ glioma hybrid cells. Neurosci. Lett. 158, 147-150. https://doi.org/10.1016/0304-3940(93)90250-O

Murata, M., Legrand, A.M., Ishibashi, Y., Fukui, M., Yasumoto, T., 1990. Structures and configurations of ciguatoxin from the moray eel Gymnothorax javanicus and its likely precursor from the dinoflagellate Gambierdiscus toxicus. J. Am. Chem. Soc. 112, 4380-4386.

Nicholson, G.M., Lewis, R.J., 2006. Ciguatoxins: Cyclic polyether modulators of voltage-gated ion channel function. Mar. Drugs 4, 82-118. https://doi.org/10.3390/md403082

O’Toole, A.C., Bottein, M.-Y.D., Danylchuk, A.J., Ramsdell, J.S., Cooke, S.J., 2012. Linking ciguatera poisoning to spatial ecology of fish: A novel approach to examining the distribution of biotoxin levels in the great barracuda by combining non-lethal blood sampling and biotelemetry. Sci. Total Environ. 427, 98-105.

Oshiro, N., Yogi, K., Asato, S., Sasaki, T., Tamanaha, K., Hirama, M., Yasumoto, T., Inafuku, Y., 2010. Ciguatera incidence and fish toxicity in Okinawa, Japan. Toxicon 56, 656-661.

Perrault, J.R., Schmid, J.R., Walsh, C.J., Yordy, J.E., Tucker, A.D., 2014. Brevetoxin exposure, superoxide dismutase activity and plasma protein electrophoretic profiles in wild-caught Kemp's ridley sea turtles (Lepidochelys kempii) in southwest Florida. Harmful Algae 37, 194-202. https://doi.org/10.1016/j.hal.2014.06.007

Pisapia, F., Holland, W.C., Hardison, D.R., Litaker, R.W., Fraga, S., Nishimura, T., Adachi, M., NguyenNgoc, L., Séchet, V., Amzil, Z., Herrenknecht, C., Hess, P., 2017. Toxicity screening of 13 Gambierdiscus strains using neuro-2a and erythrocyte lysis bioassays. Harmful Algae 63, 173-183. https://doi.org/10.1016/j.hal.2017.02.005

Poli, M.A., Mende, T.J., Baden, D.G., 1986. Brevetoxins, unique activators of voltage-sensitive sodium channels, bind to specific sites in rat brain synaptosomes. Mol. Pharmacol. 30, 129-135.

R Core Team, 2014. R: A language and environment for statistical computing. R Foundation for Statistical Computing, Vienna, Austria.

Randall, J.E., 1958. A review of ciguatera, tropical fish poisoning, with a tentative explanation of its cause. Bull. Mar. Sci. 8. 
Roué, M., Darius, H.T., Picot, S., Ung, A., Viallon, J., Gaertner-Mazouni, N., Sibat, M., Amzil, Z., Chinain, M., 2016. Evidence of the bioaccumulation of ciguatoxins in giant clams (Tridacna maxima) exposed to Gambierdiscus spp. cells. Harmful Algae 57, 78-87.

Satake, M., Ishibashi, Y., Legrand, A.-M., Yasumoto, T., 1996. Isolation and structure of ciguatoxin-4A, a new ciguatoxin precursor, from cultures of dinoflagellate Gambierdiscus toxicus and parrotfish Scarus gibbus. Biosci. Biotechnol. Biochem. 60, 2103-2105.

Tester, P.A., Feldman, R.L., Nau, A.W., Kibler, S.R., Wayne Litaker, R., 2010. Ciguatera fish poisoning and sea surface temperatures in the Caribbean Sea and the West Indies. Toxicon 56, 698-710. https://doi.org/10.1016/j.toxicon.2010.02.026

Ward, D.M., Nislow, K.H., Chen, C.Y., Folt, C.L., 2010. Rapid, efficient growth reduces mercury concentrations in stream-dwelling Atlantic salmon. Trans. Am. Fish. Soc. 139, 1-10. https://doi.org/10.1577/T09-032.1

Wilson, J.M., Bunte, R.M., Carty, A.J., 2009. Evaluation of rapid cooling and tricaine methanesulfonate (MS222) as methods of euthanasia in zebrafish (Danio rerio). J. Am. Assoc. Lab. Anim. Sci. 48, 785-9.

Yan, M., Leung, P.T.Y., Ip, J.C.H., Cheng, J., Wu, J.-J., Gu, J.-R., Lam, P.K.S., 2017. Developmental toxicity and molecular responses of marine medaka (Oryzias melastigma) embryos to ciguatoxin PCTX-1 exposure. Aquat. Toxicol. 185, 149-159.

Yang, Z., Luo, Q., Liang, Y., Mazumder, A., 2016. Processes and pathways of ciguatoxin in aquatic food webs and fish poisoning of seafood consumers. Environ. Rev. 150, 144-150. https://doi.org/10.1139/er-2015-0054

Yasumoto, T., Bagnis, R., Thevenin, S., Garcon, M., 1977. A survey of comparative toxicity in the food chain of ciguatera. Bull. Japanese Soc. Sci. Fish. 43, 1015-1019.

Yasumoto, T., Nakajima, I., Bagnis, R., Adachi, R., 1977. Finding a dinoflagellate as a likely culprit of ciguatera. Bull. Japanese Soc. Sci. Fish. 43, 1021-1026.

Yogi, K., Oshiro, N., Inafuku, Y., Hirama, M., Yasumoto, T., 2011. Detailed LC-MS/MS analysis of ciguatoxins revealing distinct regional and species characteristics in fish and causative alga from the pacific. Anal. Chem. 83, 8886-8891. https://doi.org/10.1021/ac200799j 
699 Table 1. Summary of experimental design

\begin{tabular}{cccc}
\hline Treatment & $\begin{array}{c}\text { Cumulative number of } \\
\text { feedings with cells }\end{array}$ & N & Fish collection \\
\hline Control & 0 & 3 & Initial control, sacrificed 8 h post last feeding \\
\hline 2 weeks & 10 & 5 & Dosed fish, sacrifice 8 h post last-exposure \\
4 weeks & 20 & 5 & to $G$. polynesiensis \\
8 weeks & $37^{\mathrm{b}}$ & 5 & \\
$\mathbf{1 6}$ weeks & $76^{\mathrm{b}}$ & 5 & Experimental and terminal control, sacrificed 8 \\
\hline Control & 0 & 5 & h post last feeding \\
\hline (16 weeks) & & &
\end{tabular}

${ }^{\mathrm{a}}$ Daily feeding for exposed fish consisted of 89 cells g-1 corresponding to $0.4 \mu \mathrm{g} \mathrm{CTX3C}$ equiv $\mathrm{kg}^{-1}$ fish

$701{ }^{b}$ Treatments of 8 and 16 weeks had 3 and 4 fewer dosings than expected ( 40 and 80, respectively) due to 702 lab closures. 
711 Table 2: Comparison of the quantity of ciguatoxin (CTX) ingested by the fish and that detected in the

712 muscles

\begin{tabular}{cccccc}
\hline $\begin{array}{c}\text { Week of } \\
\text { experiment }\end{array}$ & $\begin{array}{c}\text { Cumulative } \\
\text { number of } \\
\text { toxic feedings }\end{array}$ & $\begin{array}{c}\text { Mean total } \\
\text { quantity of } \\
\text { toxin ingested } \\
\left(\mathrm{ng}^{\mathrm{c}} \text { fish }^{-1}\right)\end{array}$ & $\begin{array}{c}\text { Mean muscle toxin } \\
\text { concentration }^{\mathrm{d}} \\
\left(\mu \mathrm{g}^{\mathrm{c}} \mathrm{kg}^{-1}\right)\end{array}$ & $\begin{array}{c}\text { Mean muscle toxin } \\
\text { burden }{ }^{\mathrm{C}}\left(\mathrm{ng}^{\mathrm{c}}\right)\end{array}$ & $\begin{array}{c}\text { \% toxins ingested } \\
\text { accumulated } \\
\text { in muscle }^{\mathrm{f}}\end{array}$ \\
\hline 2 & 10 & 71.6 & $1.19 \pm 0.22$ & $2.00 \pm 0.43$ & $2.5 \pm 0.45$ \\
4 & 20 & 171.9 & $1.30 \pm 0.36$ & $3.53 \pm 1.43$ & $1.8 \pm 0.68$ \\
8 & 37 & 391.9 & $3.24 \pm 0.59$ & $10.62 \pm 3.03$ & $2.6 \pm 0.50$ \\
16 & 76 & 1268.5 & $2.81 \pm 0.57$ & $23.03 \pm 3.86$ & $1.9 \pm 0.40$
\end{tabular}

$713{ }^{\mathrm{a}}$ Control fish are not included as muscle concentrations were below the limits of detection

$714{ }^{\mathrm{b}}$ calculated as the total sum added to the tank divided by the number of fish in the tank ( $\mathrm{n}=5$ in all tanks;

715 not weight adjusted)

$716{ }^{c}$ values are expressed in terms of CTX3C equiv

$717 \mathrm{~d}$ determined by receptor binding assay (mean of three independent assays) and averaged within tank

$718{ }^{\mathrm{e}}$ Muscle toxin burden is the CTX concentration multiplied by the weight of muscle tissue collected

$719{ }^{\mathrm{f}}$ Percent ingested toxins retained were calculated per fish using weighted doses (average dose per tank

720 standardized by the proportion each fish contributed to total tank biomass) and individual muscle toxin

721 burden

722

723 


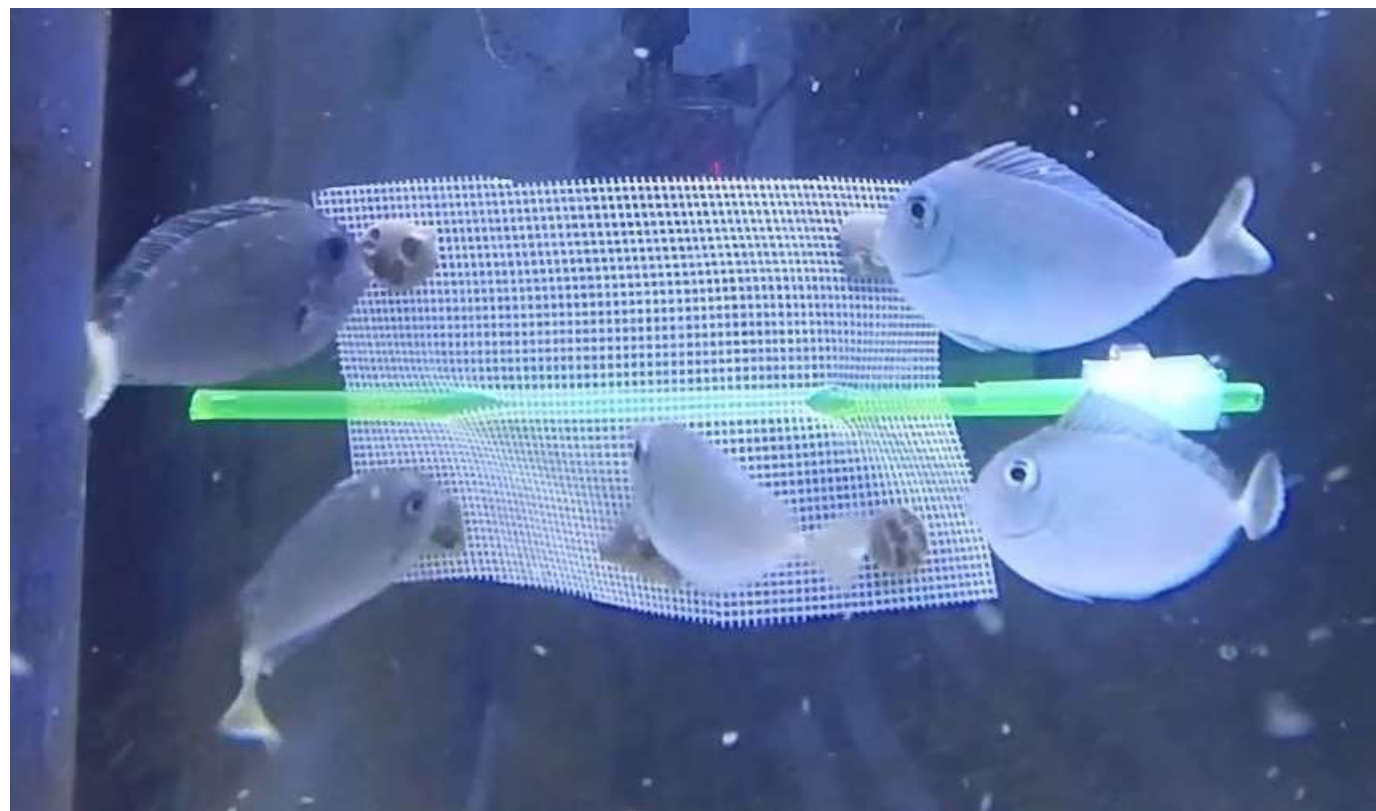

727 Figure 1. Experimental model for exposure to toxic microalgal cells: herbivorous fish graze on a gelatin-

728 based food containing Gambierdiscus cells that has been solidified on a nylon mesh and attached to the

729 aquarium wall with a plastic rod. 

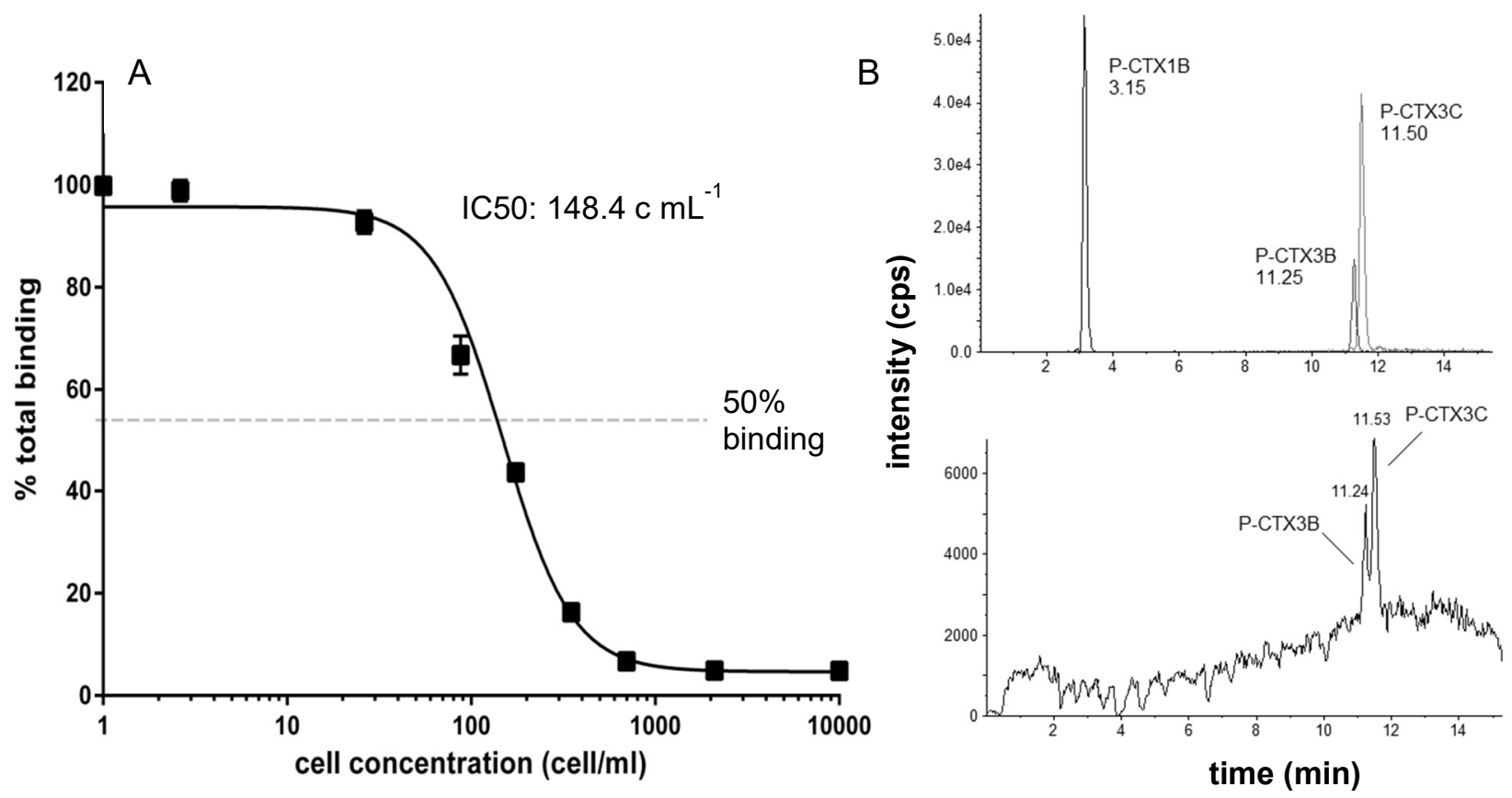

734 Figure 2. Quantification of CTXs in cells of Gambierdiscus polynesiensis (TB92) and in gel food 735 embedded with cells: A) curve depicting inhibition of binding of radiolabelled $[3 \mathrm{H}]-\mathrm{PbTx}-3$ to the 736 receptor on the voltage gated sodium channel with increasing concentrations of cells. The $\mathrm{IC}_{50}$ is the

737 concentration of cells at which the binding of $[3 \mathrm{H}]-\mathrm{PbTx}-3$ is at $50 \%$ of its maximum; $\mathrm{B}$ ) chromatogram 738 of food preparation extract depicting peaks of 49-epiCTX3C (P-CTX3B) and CTX3C, with a reference 739 chromatogram for different CTX congeners above. 


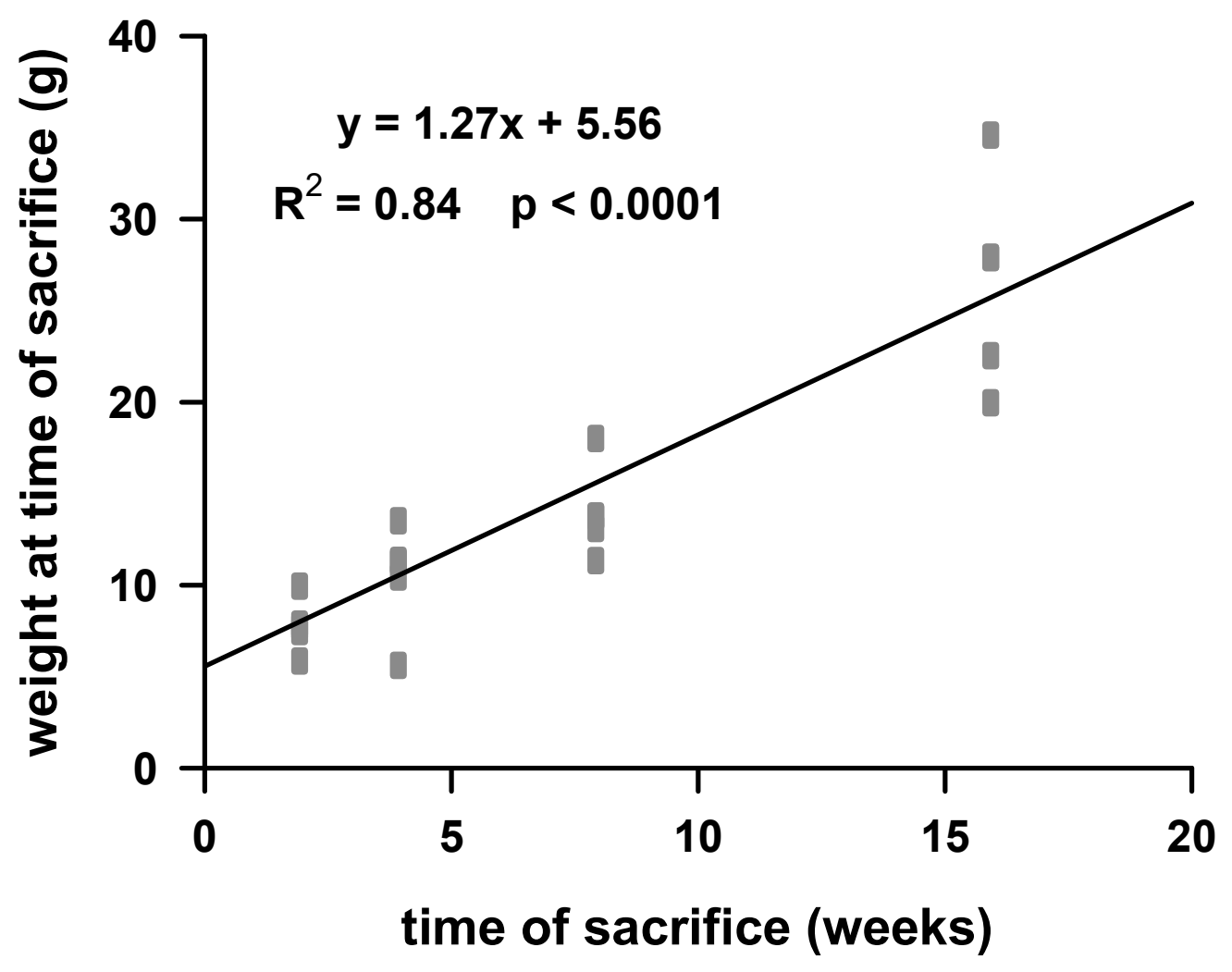

741 Figure 3. Growth curve of fish constructed from initial biomass $(\mathrm{g})$ of all fish $(\mathrm{n}=25)$ and fish weights at 742 sacrifice for each time-point $(n=5)$. The slope represents the average growth rate for a fish per week in $g$. 


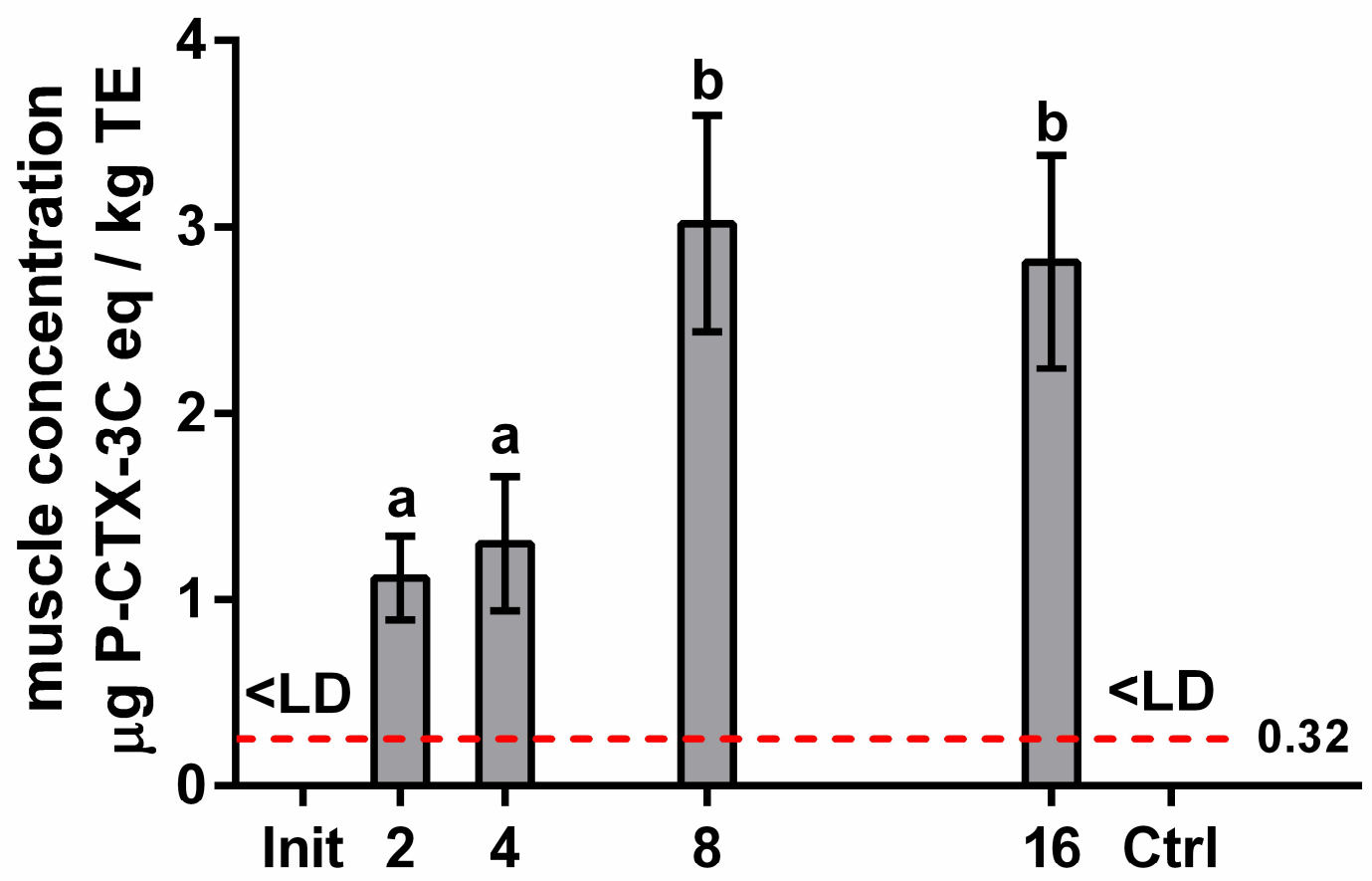

Weeks dietary exposure

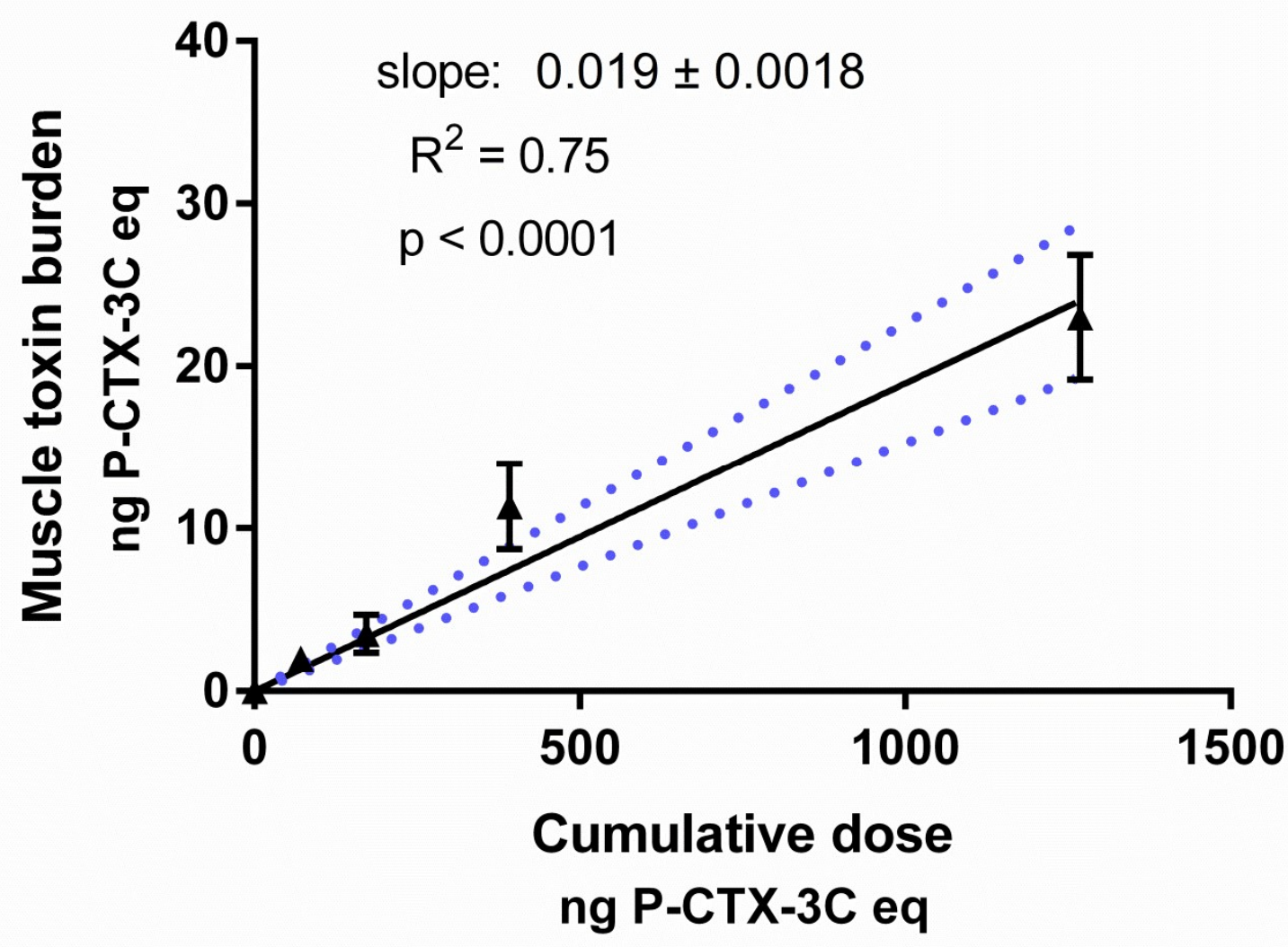


748 Figure 4. Accumulation of CTX (CTX3C equiv) in fish muscle tissue throughout the experiment as

749 measured by RBA. A) CTX concentrations in mean $\mu \mathrm{g}$ CTX3C equiv $\mathrm{kg}^{-1}$ muscle $\pm \mathrm{SEM}$, at each time 750 point (init $=$ initial control; 2, 4, 8 and 16 weeks exposure to G. polynesiensis; 16 week exposure control),

751 where concentrations in both controls were below limits of detection $(0.32 \mu \mathrm{g} \mathrm{CTX} 3 \mathrm{C}$ equiv kg-1; red 752 dotted line). Differing letters indicate significant differences among treatments at $p=0.008$ (Bonferroni 753 correction for multiple comparisons; B) CTX tissue burden (mean total ng CTX3C equiv contained in the 754 tissue \pm SEM shown here) as a function of cumulative CTX dose (ng CTX3C equiv). Linear regression 755 was performed on all data and was significant at $p<0.0001$. Blue dotted lines are $95 \%$ CIs of the slope. 